\title{
Effects of contrasting patterns of larval dispersal on the genetic connectedness of local populations of two intertidal starfish, Patiriella calcar and $P$. exigua*
}

\author{
Alison Hunt \\ Department of Biology, University of Wollongong, Locked Bag 8844, South Coast Mail Centre, Wollongong. \\ New South Wales 2521, Australia
}

\begin{abstract}
The closely related intertidal starfish Patiriella calcar and $P$. exigua have markedly different dispersal capabilities. $P$. calcar is considered to have sexually produced planktonic larvae and hence the potential for wide dispersal. If this is the case local populations should be strongly interconnected and there should be little or no accumulation of genetic variation. Conversely, $P$. exigua has no known means of dispersal between local populations since development proceeds directly from egg masses laid on the rocky shore. Therefore, local populations of $P$. exigua may be less genotypically diverse than $P$. calcar, but should display marked genetic heterogeneity among local populations resulting from the accumulating effects of genetic drift and localised natural selection. To test these predictions genetic data were used to assess the genotypic structure and apparent connectedness of local populations of both species along $230 \mathrm{~km}$ of the southeast coast of Australia. Electrophoretic variation was surveyed for 5 loci. Single-locus genotype frequencies within all local populations of both species closely matched expectations for Hardy-Weinberg equilibria. This implies that local populations are maintained by recruitment of outcrossed sexually produced offspring, but as predicted, $P$. exigua had fewer alleles at each locus and fewer heterozygous individuals than $P$. calcar. Furthermore, it appears that these 2 species have vastly different levels of gene flow among local populations. The 6 local populations of $P$. calcar were genetically homogeneous $\left[F_{\mathrm{ST}}=0 \pm 0.001\right.$ (SE)] and these populations were thus inferred to be strongly connected by larval dispersal. In sharp contrast, the 11 local populations of the directly developing $P$. exigua were highly genetically heterogeneous which is reflected in consistently high levels of genetic variance $\left(F_{\mathrm{ST}}=0.462 \pm 0.048\right)$.
\end{abstract}

\section{INTRODUCTION}

Echinoderms are a conspicuous and important component of many marine environments (e.g. Paine 1966, Benzie \& Stoddart 1992). This has provoked enormous interest in the great diversity of echinoderm life histories, and these have been shown to include species which are brooders (Chia 1966, Keough \& Dartnall 1978), species which undergo asexual replication of sexually produced planktonic larvae (Bosch et al. 1989)

\footnotetext{
- Publication No. 98 from the Ecology and Genetics Group of
} the University of Wollongong or asexual replication by fission or autotomy (Emson \& Wilkie 1980), broadcast spawning of sexually produced gametes (Barker \& Nichols 1983) and species which combine modes of reproduction and means of dispersal (Johnson \& Threlfall 1987, McClary \& Mladenov 1989).

Many recent studies have demonstrated the value of genetic data in determining local population structure and inferred dispersal distances for marine organisms (e. g. Koehn et al. 1976, Burton \& Feldman 1981, Grosberg 1987, Ayre \& Willis 1988, Hunt \& Ayre 1989, Johnson \& Black 1990) and echinoderms in particular (e.g. Kwast et al. 1990, Palumbi \& Kessing 1991, Benzie 
\& Stoddart 1992) and have often overturned predictions based solely upon histological or ecological data. Consequently, the present study uses genetic data to assess the mode of reproduction and apparent scale of dispersal of 2 species of co-occurring intertidal starfish, Patiriella exigua (Lamarck) and P. calcar (Lamarck). Both species are common and have similar geographic ranges along the southeastern coast of Australia (Dartnall 1971). P. calcar is believed to disperse via sexually produced planktonic larvae (Lawson-Kerr \& Anderson 1978, Byrne 1991) which remain in the planktonic stage for ca $10 \mathrm{~d}$ (Lawson-Kerr \& Anderson 1978). It therefore has the potential for wide dispersal. Conversely, dispersal of $P$. exigua is thought to be severely restricted as juveniles develop directly from egg masses deposited onto the rocky shore (Lawson-Kerr \& Anderson 1978, Byrne 1991). Although the mating system of this species is unknown there is some evidence to suggest that $P$. exigua may be protandric and/or simultaneously hermaphroditic (Byrne 1991). Neither P. calcar or $P$ exigua is known to reproduce asexually.

Philopatry, or restricted dispersal, in the absence of selection, should result in both low levels of variability due to a reduction in the effective population size (Soulé 1976, Gallardo \& Perron 1982), and genetic divergence of local populations, as the effects of drift and localised selection may accumulate each generation due to offspring remaining within the parental habitat (Wright 1968). Although this issue has been considered for many years (e.g. see Gooch \& Schopf 1970) few studies have dealt directly with the effects of restricted dispersal on the genetic structure of populations (e.g. Burton \& Feldman 1981, Kwast et al. 1990, Ward 1990, Johnson \& Black 1991, Siegismund \& Müller 1991), and none have looked at species from the southeast coast of Australia (Ayre 1990).

In contrast, high genetic diversity within local populations and genetic homogeneity among populations characterise a species with wide dispersal of sexually produced planktonic larvae. However, the wide dispersal of sexually produced planktonic larvae will typically only be possible by transport via ocean currents, and a species with planktonic larvae may experience quite restricted dispersal if the current flow is disjointed or unreliable. The unpredictable nature of the major current flow along the southeast coast of Australia, the East Australian Current, may strongly influence patterns of dispersal along this coastline. This current flows in a southerly direction along the eastern coast of Australia but is also composed of a complex set of eddies (Hamon 1965) before finally moving offshore to the east at the southeastern corner of Australia (Hamon et al. 1975). The use of genetic data is therefore essential as a means of inferring realised rather than potential dispersal distances.
This study examined the genotypic composition of local populations of the 2 species of intertidal starfish, Patiriella exigua and $P$. calcar, in order to infer their mode of reproduction and source of most recruitment. Gene frequencies were then used to investigate the consequences of philopatry and wide dispersal for the genetic connectedness of local populations.

\section{METHODS}

Collections of samples. Starfish were collected from stable intertidal rock platforms, over a total distance of $230 \mathrm{~km}$, between Kurnell $\left(34^{\circ} 2^{\prime} \mathrm{S}, 151^{\circ} 12^{\prime} \mathrm{E}\right)$ and Durras $\left(35^{\circ} 40^{\prime} \mathrm{S}, 150^{\circ} 18^{\prime} \mathrm{E}\right)$ on the southeast coast of Australia. Samples of 29 to 48 individuals of Patiriella calcar and $P$. exigua were collected from each of 6 and 11 separate headlands (local populations) respectively, including 4 sites in which they co-occurred. Starfish were transported to the laboratory alive and then stored frozen at $-80^{\circ} \mathrm{C}$ pending electrophoretic analysis.

Electrophoresis. Tissue extracts were prepared for each individual by macerating a small portion of arm in a $10 \%$ sucrose solution. Electrophoresis was carried out on horizontal starch gels ( $12 \% \mathrm{w} / \mathrm{v})$ using methods modified from Harris \& Hopkinson (1976). Each species of starfish was assayed for 5 enzyme encoding loci: Gpi, Pgm, Hk, Mdh and Sod for Patiriella calcar, and Gpi, Pgm, Hk, Lpp and Ltp for P. exigua. Gpi was apparently dimeric in both species as was $L p p$ in $P$. exigua. Mdh appeared to be dimeric for 2 enzymes although only locus 1 could be consistently scored. All other enzymes in both species were assumed to be monomeric and encoded by 1 scorable locus. The electrophoretic buffers used were No. 5 for $L t p, L p p, M d h$, Sod and No. 9 for Gpi, Hk, and Pgm as described and numbered by Selander et al. (1971). Alleles were labelled alphabetically in order of decreasing mobility and a 5-locus genotype was inferred for each individual.

Analysis of intra-population variation. Regardless of whether recruits are the product of widespread dispersal or direct development, the genotypic structure of local populations can be used to infer the mating system of the species. Allozyme data were used to assess the levels and patterns of genotypic diversity present within local populations. Departures of genotype frequencies from those expected under HardyWeinberg equilibria were estimated for all loci at all sites as well as an overall estimate for each species $\left(F_{1 S}\right)$. Deficits of heterozygous individuals relative to those expected under Hardy-Weinberg equilibrium are reflected in positive values and may indicate subdivision of the population on some scale due to inbreeding and Wahlund effects, whereas asexual repro- 
duction can lead to both excesses and deficits. The statistical significance of the departures of the observed number of heterozygotes from those expected under Hardy-Weinberg equilibria were calculated by chisquare goodness of fit analyses with 2 categories, homozygotes and heterozygotes (Zar 1984, p. 42).

Although single-locus genotype frequencies may return to Hardy-Weinberg equilibrium after 1 generation of random mating, the association between alleles at different loci can persist for many generations (Waller \& Knight 1989) and may reflect past episodes of inbreeding or asexual reproduction, random drift, selection, mutations or the mixing of genetically distinct populations (Crow \& Kimura 1970, Hedrick et al. 1978). Therefore it was important to look at multi-locus genotype frequencies in order to provide a more sensitive test of the history of patterns of mating and recruitment. Hill's (1974) diallelic pairwise linkage disequilibrium measure was used to test for the presence of inter-locus associations. Although the sample sizes in this study are such that low intensities of disequilibrium will probably not be detected this test will allow relatively intense levels of disequilibrium to be detected (Brown 1975). For each comparison the most locally common allele plus all other alleles at that locus were compared to all other loci within each local population. Chi-square analyses were used to determine the statistical significance of disequilibrium in each case.

Inter-population variation. The level of genetic differentiation of local populations provides an indication of the level of gene flow and can be estimated as the standardised variance in allelic frequencies, $F_{\text {ST }} . F_{\text {ST }}$ was calculated among samples for each allele and each locus using the formulation of Wright (1978) (BIOSYS-1 program; Swofford \& Selander 1981). To provide a less biased estimate of the mean $F_{\mathrm{ST}}$ across all loci, a jackknife estimate of $F_{\mathrm{ST}}$ and its variance $(\theta \pm \mathrm{SE})$ was also calculated using the method of Weir \& Cockerham (1984). For each locus the statistical significance of the inter-population variation in allelic frequencies was calculated by heterogeneity chi-square analysis. To ensure validity of these tests, rare alleles were pooled with the next most common allele for each locus to ensure that all chi-square cells contained expected values $>4$.

The overall pattern of allelic frequency variation at polymorphic loci in Patiriella exigua was assessed by

Table 1 Patiriella calcar. Allelic frequencies for 5 enzyme-encoding loci for collections from local populations separated by 230 $\mathrm{km}$ on the southeast coast of Australia. Local populations listed from north to south. Sample size given in parentheses. -: allele absent

\begin{tabular}{|c|c|c|c|c|c|c|}
\hline $\begin{array}{l}\text { Locus } \\
\text { Allele }\end{array}$ & $\begin{array}{c}\text { Kurnnell } \\
\text { (29) }\end{array}$ & $\begin{array}{c}\text { Woonona } \\
\text { (43) }\end{array}$ & $\begin{array}{l}\text { Bellambi } \\
\text { (39) }\end{array}$ & $\begin{array}{c}\text { Nth Beach } \\
(45)\end{array}$ & $\begin{array}{l}\text { Ulladulla } \\
\text { (41) }\end{array}$ & $\begin{array}{c}\text { Durras } \\
(29)\end{array}$ \\
\hline \multicolumn{7}{|l|}{ Gpi } \\
\hline $\mathrm{a}$ & 0.018 & 0.035 & 0.026 & 0.033 & 0.037 & - \\
\hline$b$ & 0.052 & 0.186 & 0.115 & 0.089 & 0.146 & 0.018 \\
\hline c & 0.483 & 0.337 & 0.397 & 0.478 & 0.341 & 0.362 \\
\hline $\mathrm{d}$ & 0.310 & 0.302 & 0.269 & 0.300 & 0.268 & 0.414 \\
\hline e & 0.103 & 0.128 & 0.179 & 0.100 & 0.159 & 0.172 \\
\hline $\mathrm{f}$ & 0.034 & 0.012 & 0.014 & - & 0.049 & 0.034 \\
\hline \multicolumn{7}{|l|}{ Pgm } \\
\hline a & 0.017 & 0.046 & 0.051 & 0.056 & 0.037 & - \\
\hline $\mathrm{b}$ & 0.897 & 0.884 & 0.872 & 0.900 & 0.951 & 0.897 \\
\hline$c$ & 0.086 & 0.070 & 0.077 & 0.044 & 0.012 & 0.103 \\
\hline \multicolumn{7}{|l|}{$H k$} \\
\hline$a$ & 0.017 & - & 0.013 & - & - & - \\
\hline b & 0.017 & 0.012 & 0.013 & 0.044 & 0.024 & 0.069 \\
\hline c & 0.224 & 0.314 & 0.269 & 0.200 & 0.268 & 0.190 \\
\hline d & 0.690 & 0.627 & 0.564 & 0.644 & 0.671 & 0.707 \\
\hline e & 0.052 & 0.035 & 0.128 & 0.100 & 0.037 & 0.034 \\
\hline $\mathrm{f}$ & - & 0.012 & 0.013 & 0.012 & - & - \\
\hline \multicolumn{7}{|l|}{$M d h$} \\
\hline $\mathrm{a}$ & 0.155 & 0.198 & 0.282 & 0.234 & 0.244 & 0.276 \\
\hline b & 0.828 & 0.779 & 0.718 & 0.722 & 0.756 & 0.707 \\
\hline$c$ & 0.017 & 0.023 & - & 0.044 & - & 0.017 \\
\hline \multicolumn{7}{|l|}{ Sod } \\
\hline a & - & - & 0.013 & - & - & - \\
\hline b & 1.000 & 1.000 & 0.987 & 1.000 & 1.000 & 1.000 \\
\hline
\end{tabular}


Nei's (1978) unbiased measure of genetic identity. A dendrogram produced by the UPGMA clustering technique (Sokal \& Sneath 1963) was used to summarise the genetic similarity of local populations.

\section{RESULTS}

\section{Intra-population variation}

The genotypic composition of samples from local populations of both Patiriella calcar and $P$. exigua were consistent with the genetic structure of local populations maintained by recruitment of sexually produced offspring. Four of the five loci examined for $P$. calcar were highly polymorphic with an average of $4.0 \pm 0.3$ ( $\pm \mathrm{SE}$ ) alleles per locus and on average $1.6 \pm 0.1$ ( $\pm \mathrm{SE}$ ) loci were heterozygous per individual (Table 1), however, the Sod locus was polymorphic in only 1 individual at Bellambi. Almost all individuals had unique 5-locus genotypes and genotype frequencies were in close agreement with expectations for HardyWeinberg equilibria for all loci and all local populations with only a slight overall deficit of heterozygotes ( $F_{\text {IS }}$ weighted mean $\left.=0.065\right)$. None of the 13 deficits or 10 excesses of heterozygotes found proved to be significantly different from Hardy-Weinberg expectations. Additionally, no linkage disequilibrium ( $p>0.05)$ was found between any loci within the 6 local populations of P. calcar.

Similarly, genotype frequencies within local populations of Patiriella exigua typically provided a close fit to expectations for Hardy-Weinberg equilibria (Table 2) with only slight deficits of heterozygous individuals $\left(F_{\mathrm{IS}}\right.$ weighted mean $\left.=0.098\right)$. Only 2 of the 16 cases of deficits from Hardy-Weinberg equilibria were statistically significant and these were both at the Ltp locus in samples from Sandon Pt. $(p<0.05)$ and Kioloa $(\mathrm{p}<0.001)$ but none of the 17 excesses. Furthermore, no cases of statistically significant linkage disequilibrium were detected $(p>0.05)$ in any of the 11 local populations. The 5 loci examined for $P$. exigua were less polymorphic than those of $P$. calcar and on average ( $\pm \mathrm{SE}$ ) there were $1.8 \pm 0.1$ alleles per locus and $0.8 \pm$ 0.0 loci heterozygous per individual. Nonetheless, all 5 loci could be considered polymorphic although variation at the $H k$ locus was only found at Pt Kembla where 6 individuals contained the alternate $H k^{a}$.

\section{Inter-population variation}

Local populations of Patiriella calcar and $P$. exigua displayed markedly different levels of genetic differentiation.

Patiriella calcar showed no appreciable allelic varia-

Table 2. As in Table 1 but for Patiriella exigua

\begin{tabular}{|c|c|c|c|c|c|c|c|c|c|c|c|}
\hline $\begin{array}{l}\text { Locus } \\
\text { Allele }\end{array}$ & $\begin{array}{c}\text { Garie } \\
\text { Beach } \\
(4 \vec{\gamma})\end{array}$ & $\begin{array}{c}\text { Sandon } \\
\text { Pt } \\
(36)\end{array}$ & $\begin{array}{l}\text { Woo- } \\
\text { nona } \\
(35)\end{array}$ & $\begin{array}{c}\text { Bell- } \\
\text { ambi } \\
(45)\end{array}$ & $\begin{array}{c}\text { Nth } \\
\text { Beach } \\
(40)\end{array}$ & $\begin{array}{c}\text { Sth } \\
\text { Beach } \\
(43)\end{array}$ & $\begin{array}{c}\text { Port } \\
\text { Kembla } \\
(40)\end{array}$ & $\begin{array}{c}\text { Windang } \\
\text { Is. } \\
\text { (36) }\end{array}$ & $\begin{array}{c}\text { Bass } \\
\mathrm{Pt} \\
(46)\end{array}$ & $\begin{array}{l}\text { Kioloa } \\
\text { (48) }\end{array}$ & $\begin{array}{c}\text { Durras } \\
(33)\end{array}$ \\
\hline \multicolumn{12}{|l|}{ Gpi } \\
\hline$a$ & 0.957 & 1.000 & 1.000 & 0.556 & 0.762 & 0.477 & 0.200 & - & 0.054 & 0.917 & 1.000 \\
\hline$b$ & 0.011 & - & - & - & - & - & - & - & - & - & - \\
\hline c & 0.021 & - & - & 0.444 & 0.238 & 0.523 & 0.788 & 1.000 & 0.946 & 0.083 & - \\
\hline d & 0.011 & - & - & - & - & - & 0.012 & - & - & - & - \\
\hline \multicolumn{12}{|l|}{$P g m$} \\
\hline $\mathrm{a}$ & 0.021 & - & - & - & 0.125 & 0.035 & 0.038 & 0.014 & 0.065 & - & - \\
\hline$b$ & 0.979 & 1.000 & 1.000 & 0.967 & 0.875 & 0.965 & 0.962 & 0.986 & 0.935 & 1.000 & 1.000 \\
\hline $\mathrm{c}$ & - & - & - & 0.033 & - & - & - & - & - & - & - \\
\hline \multicolumn{12}{|l|}{$H k$} \\
\hline $\mathrm{a}$ & - & - & - & - & - & - & 0.100 & - & - & - & - \\
\hline$b$ & 1.000 & 1.000 & 1.000 & 1.000 & 1.000 & 1.000 & 0.900 & 1.000 & 1.000 & 1.000 & 1.000 \\
\hline \multicolumn{12}{|l|}{$L p p$} \\
\hline $\mathrm{a}$ & 0.138 & 0.597 & 0.773 & 0.056 & 0.512 & 0.267 & 0.888 & 0.042 & 0.163 & 1.000 & 0.758 \\
\hline$b$ & 0.724 & 0.292 & - & - & - & 0.058 & 0.062 & - & 0.033 & - & - \\
\hline$c$ & 0.138 & 0.111 & 0.227 & 0.944 & 0.488 & 0.675 & 0.050 & 0.958 & 0.804 & - & 0.242 \\
\hline \multicolumn{12}{|l|}{ Ltp } \\
\hline $\mathrm{a}$ & - & - & - & 0.011 & & - & - & - & - & - & - \\
\hline b & 0.638 & 0.875 & 0.985 & 0.989 & 0.988 & 0.779 & 0.725 & 0.917 & 0.870 & 0.552 & 0.652 \\
\hline c & 0.351 & 0.125 & 0.015 & - & 0.012 & 0.221 & 0.275 & 0.083 & 0.130 & 0.448 & 0.348 \\
\hline $\mathrm{d}$ & 0.011 & - & - & - & - & - & - & - & - & - & - \\
\hline
\end{tabular}


Table 3. Patiriella calcar. Allelic frequency variation for 5 enzyme-encoding loci among samples. $F_{\mathrm{ST}}$ : standardised variance (Wright 1978). $\theta \pm$ SE obtained by jacknife procedure (Weir \& Cockerham 1984). Probability: heterogeneity chisquare analysis for each locus. NS: not significant at $p<0.05$. nt: valid chi-square could not be tested

\begin{tabular}{|lcc|}
\hline Locus & $F_{\text {ST }}$ & Probability \\
\hline Gpi & 0.003 & NS \\
Pgm & 0.000 & NS \\
$H k$ & 0.001 & NS \\
Mdh & 0.000 & NS \\
Sod & 0.000 & $\mathrm{nt}$ \\
$\theta \pm \mathrm{SE}$ & \multicolumn{2}{c}{$0.000 \pm 0.001$} \\
\hline
\end{tabular}

tion among 6 local populations $\left(F_{\mathrm{ST}}=0.000 \pm 0.001\right)$ (Table 3 ). F sr values for individual alleles, weighted averages for each locus, and across all loci, ranged from 0 for all alleles at 3 loci to 0.023 for the relatively rare $G p i^{\text {b }}$. Only Gpi and $H k$ had measurable, although not significant $(\mathrm{p}>0.05), \mathrm{F}_{\mathrm{ST}}$ values of 0.003 and 0.001 respectively (Table 3 ).

In contrast, allelic frequencies for Patiriella exigua varied greatly among the 11 local populations $\left(F_{\mathrm{ST}}=\right.$ $0.462 \pm 0.048$ ) (Table 4). All alleles, except for those which were extremely rare, had high genetic variances and these ranged from 0.020 for $P g m^{c}$ to 0.607 for $G p i^{c}$. Variation at the Gpi, Lpp and $L$ tp loci was highly significant $(\mathrm{p}<0.0001)$ and resulted in $F_{\mathrm{ST}}$ values of 0.601 , 0.469 and 0.143 respectively. Low levels of polymorphism at Pgm and $H k$ are reflected in the lower, but still high, $F_{\mathrm{ST}}$ values of 0.036 and 0.080 respectively. The statistical significance of allelic heterogeneity for these 2 loci could not be tested because of small expected values. However, the differentiation of local populations was such that 4 of the 6 loci contained at least 1 allele that was unique to only 1 local population (Table 2). Furthermore, at both the Gpi and Lpp loci there was no allele which was the most common in all cases, and in fact all 3 alleles at the $L p p$ locus were the most common allele in at least 1 local population. There was no clear geographic pattern to this allelic variation for $P$. exigua (Fig. 1).

Table 4. As in Table 3 but for Patiriella exigua.

\begin{tabular}{|lcc|}
\hline Locus & $F_{\mathrm{ST}}$ & Probability \\
\hline Gpi & 0.601 & $<0.0001$ \\
$P g m$ & 0.036 & $\mathrm{nt}$ \\
$H k$ & 0.080 & $\mathrm{nt}$ \\
Lpp & 0.469 & $<0.0001$ \\
Ltp & 0.143 & $<0.0001$ \\
$\theta \pm \mathrm{SE}$ & \multicolumn{2}{c}{$0.462 \pm 0.048$} \\
\hline
\end{tabular}
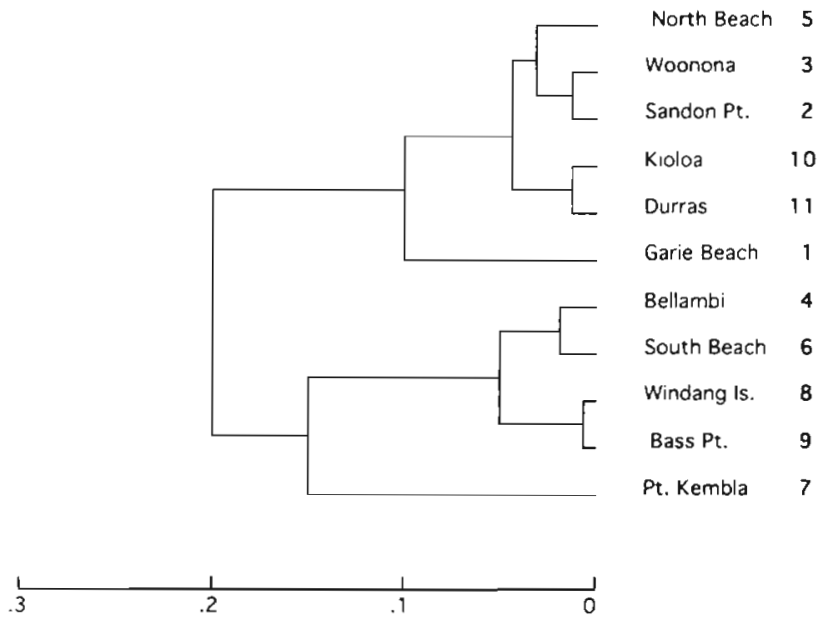

Genetic Distance

Fig. 1. UPGMA dendrogramm (Sokal \& Sneath 1963) showing the genetic relatedness of 11 samples of Patiriella exigua collected over $230 \mathrm{~km}$ of the southeast coast of Australia as estimated by Nei's (1974) unbiased minimum genetic distance

(D). Local populations are numbered from north to south

\section{DISCUSSION}

The genetic structure of local populations of Patiriella exigua and $P$. calcar are consistent with the predicted effects of recruitment via sexually produced offspring, although with very different patterns of dispersal.

\section{Reproduction and recruitment}

In contrast with several recent studies of other species of echinoderms (e.g. Emson \& Wilkie 1980, Bosch et al. 1989, McClary \& Mladenov 1989) there was no evidence to suggest asexual reproduction for either species as genotype frequencies within samples from each local population were in close agreement with expectations for Hardy-Weinberg equilibrium and the majority of individuals had unique 5-locus genotypes. The weighted average $F_{\text {IS }}$ value of 0.065 for Patiriella calcar and 0.098 for $P$. exigua indicates an overall slight deficit of heterozygotes as compared with expections for Hardy-Weinberg equilibria. However, only 2 local populations of $P$. exigua had significant deficits of heterozygotes and these were both at the Ltp locus. Such isolated departures are not attributable to the mode of reproduction as the breeding system of the organism affects all loci equally but may suggest selection favouring homozygosity at that locus. In fact, such a good fit to Hardy-Weinberg expectations is uncommon as a deficiency of heterozygous individuals tend to 
characterise marine invertebrate populations (e.g Koehn et al. 1976, Johnson \& Black 1984, Foltz 1986 , Kwast et al. 1990, Grant \& Lang 1991) (but see Grant \& Lang 1991).

\section{Genetic connectedness}

Differences in the dispersal capabilities of Patiriella calcar and $P$. exigua are reflected in the inter-population allelic variation. As was predicted, due to the presence of a planktonic larvae, local populations of $P$. calcar appear to be strongly interconnected. There was little detectable variation in allelic frequencies for populations separated by up to $230 \mathrm{~km}$. The overall $F_{\mathrm{ST}}$ value of $0 \pm 0.001$ was well within the range expected for a sexually reproducing species with widespread dispersal (Levinton \& Suchanek 1978, Johnson \& Black 1984 ). Low levels of genetic variation among local populations have been demonstrated for other marine species (e.g. Koehn et al. 1976, Levinton \& Suchanek 1978, Johnson \& Black 1984, Hunt \& Ayre 1989, Benzie \& Stoddart 1992) and are thought to be the result of dicpersal of sexually produced planktonic larvae.

In sharp contrast to the apparently panmictic breeding unit of Patiriella exigua, local populations of $P$. exigua appear to be, at most, only weakly connected with the majority of recruits coming from within local populations. There was marked inter-population variation in allelic frequencies at all loci for $P$. exigua $\left(F_{\mathrm{ST}}=\right.$ $0.462 \pm 0.048$ ), and unlike $P$. calcar in which only those alleles which were shared by all sites reached high frequencies, patchily distributed alleles reached high frequencies in a few localities of $P$. exigua. However, there was no apparent geographic pattern to this allelic variation. Such haphazard allelic variation and high frequencies of patchily distributed alleles are a predictable consequence of limited gene flow and increased genetic drift (Slatkin 1981, Grant \& Utter 1988) and although there have been no comparable studies on the east coast of Australia, a few studies elsewhere have revealed similar patterns of variation for species with restricted dispersal (e.g. intertidal gastropods: Ward 1990, Johnson \& Black 1991; starfish: Kwast et al. 1990; freshwater amphipod: Siegismund \& Müller 1991; marine copepod: Burton \& Feldman 1981).

A further consequence of restricted gene flow is that local populations will have lower levels of variability due to a reduction in effective population size, which consequently increases susceptibility to genetic drift and the accumulated effects of localised selection (Soule 1976, Gallardo \& Perron 1982) and this was the case for Patiriella exigua and $P$. calcar. $P$. exigua has fewer alleles at each locus and fewer heterozygous individuals than $P$. calcar
It would appear that local populations of Patiriella exigua do not regularly receive recruits from outside sources. Furthermore, the absence of intense linkage disequilibrium within populations suggests that they have not recently been subject to population bottlenecks or close inbreeding (Waller \& Knight 1989) as has been demonstrated for some species with restricted dispersal (e.g. Foltz et al. 1982). Instead it would seem that these samples were taken from randomly mating, isolated local populations; however, further fine-scale sampling is required to confirm this. Conversely, local populations of $P$. calcar sampled in this study appear to form a large and undifferentiated panmictic group in which genetic exchange between local populations would prevent the effects of drift or selection from accumulating. Such strong interconnectedness must be a consequence of the southerly flow of the East Australian Current despite its unpredictability; this has been shown to be the case for 2 other marine species on the southeast coast of Australia, Pyura stolonifera (Killingly 1976) and Oulactis muscosa (Hunt \& Ayre 1989). The East Australian Current may have important consequences for the genetic composition of southern and eastern populations of species along this coastline as there is some evidence to suggest that movement of the coast near the southeastern corner of Australia may effectively divide species into eastern and southern populations (Ayre et al. 1991). Further sampling will be required to assess the potential impact of the divergence of the East Australian Current on more southerly local populations of $P$. calcar and $P$. exigua.

Acknowledgements. I am especially grateful to my supervisor, David Ayre, for his advice and encouragement throughout this study and invaluable criticism of this manuscript. I thank K. Ayre, S. Schibeci, R. Standish and C. Styan for providing useful comments on this manuscript and D. J. Ayre and K. Ayre for collection of Ulladulla specimens. T Holtsford's program (Version 2) was used to calculate jackknife estimates of $F_{\mathrm{ST}}$. I gratefully acknowledge the financial support provided by the University of Wollongong

\section{LITERATURE CITED}

Ayre, D. J. (1990). Population subdivision in Australian tem.perate marine invertebrates: larval connections versus historical factors. Aust. J. Ecol. 15: 403-412

Ayre, D. J., Read, J., Wishart, J. (1991). Genetic subdivison within the eastern Australian population of the sea anemone Actunia tenebrosa. Mar. Biol. 109: 379-39

Ayre, D. J., Willis, B. L. \{1988\}. Population structure in the coral Pavona cactus: clonal genotypes show little phenotypic plasticity. Mar. Biol. 99: 495-505

Barker, M. F., Nichols, D. (1983). Reproduction, recruitment and juvenile ecology of the starfish, Asterias rubens and Marthasterias glacialis. J. mar. biol. Ass. U.K. 63: $745-765$

Benzie, J. A. H., Stoddart, J. A. (1992). Genetic structure of 
outbreaking and non-outbreaking crown-of-thorns starfish (Acanthaster planci) populations on the Great Barrier Reef. Mar. Biol. 112: 119-130

Bosch, I., Rivkin, R. B., Alexander, S. P. (1989). Asexual reproduction by oceanic planktotrophic echinoderm larvae. Nature 337: 169-170

Brown, A. H. D. (1975). Sample sizes required to detect linkage disequilibrium between 2 or 3 loci. Theor popul. Biol. 8: 184-201

Burton, R.S., Feldman, M. W. (1981). Population genetics of Tigriopus californicus. II. Differentiation among neighbouring populations. Evolution 35: 1192-1.205

Byrne, M. (1991). Developmental diversity in the starfish genus Patiriella (Asteroidea: Asterinidae). In: Yanagisawa, T., Yasumasu, I., Oguro, C., Suzuki, N., Motokawa, T. (eds.) Biology of echinodermata. Balkema, Rotterdam, p. $499-508$

Chia, F.-S. (1966). Brooding behaviour of a six-rayed starfish, Leptasterias hexactis. Biol. Bull. 130: 304-315

Crow, J. F., Kimura, M. (1970). An Introduction to population genetics theory. Burgess Publ. Co.. Minneapolis

Dartnall, A. J. (1971). Australian sea stars of the genus Patiriella (Asteroidea, Asterinidae). Proc. Linn. Soc. N.S.W. 96: $39-51$

Emson, R. H., Wilkie, I. C. (1980). Fission and autotomy in Echinoderms. Oceanogr. mar. Biol. A. Rev. 18: 155-250

Foltz, D. W. (1986). Null alleles as a possible cause of heterozygote deficiencies in the oyster Crassostrea virginica and other bivalves. Evolution 40: 869-870

Foltz, D. W., Schaitkin, B. M., Selander, R. K. (1982). Gametic disequilibrium in the self-fertilizing slug Deroceras laeve. Evolution 36: 80-85

Gallardo, C. S., Perron, F. E. (1982). Evolutionary ecology of reproduction in marine benthic molluscs. Malacologia 22: $109-114$

Gooch, J. L., Schopf, T. J. M. (1970). Population genetics of marine species of the phylum Ectoprocta. Biol. Bull. 138: $138-156$

Grant, W. S., Lang, M. (1991). Mode of larval development and genetic population structure in Nodilittorina africana knysnaensis (Prosobranchia: Littorinidae). Mar Biol. 109: $479-483$

Grant, W. S., Utter, F. M. (1988). Genetic heterogeneity on different geographic scales in Nucella lamellosa (Prosobranchia, Thaididae). Malacologia 28: 275-287

Grosberg, R. K. (1987). Limited dispersal and proximitydependent mating success in the colonial ascidian Botryllus schlosseri. Evolution 41: 372-384

Hamon, B. V. (1965). The East Australian Current (1960-1964). Deep Sea Res. 12: 899-921

Hamon, B. V., Godfrey, J. S., Greig, M. A. (1975). The relation between mean sea level, current and wind stress on the east coast of Australia. Aust. J. mar. freshwat. Res. 26: 389-403

Harris, H., Hopkinson, D. A. (1976). Handbook of enzyme electrophoresis in human genetics. North-Holland Publishing Co. Inc., Amsterdam

Hedrick, P., Jain, S., Holden, L. (1978). Multilocus systems in evolution. Evol. Biol. 11: 101-184

Hill, W. G. (1974). Estimation of linkage disequilibrium in randomly mating populations. Heredity 33: 229-239

Hunt, A., Ayre, D. J (1989). Population structure in the sexually reproducing sea anemone Oulactis muscosa. Mar. Biol. 102: $537-544$

Johnson, M. S., Black, R. (1984). The Wahlund effect and the geographical scale of variation in the intertidal limpet Siphonaria sp. Mar. Biol. 79: 295-302
Johnson, M. S., Black, R. (1990). Genetic divergence of venerid clams in Shark Bay, Western Australia. In: Berry, P. F., Bradshaw, S. D.. Wilson, B. R. (eds.) Research in Shark Bay. W. A. Museum, Perth, p. 159-168

Johnson, M. S., Black, R. (1991). Genetic subdivision of the intertidal snail Bembicium vittatum (Gastropoda: Littorinidae) varies with habitat in the Houtman Abrolhos Islands, Western Australia. Heredity 67: 205-213

Johnson, M. S., Threlfall, T J. (1987). Fissiparity and population genetics of Coscinasterias calamaria. Mar. Biol. 93: $517-525$

Keough, M. J., Dartnall, A. J. (1978). A new species of viviparous asterinid asteroid from Eyre Peninsula, South Australia. Rec. S. Aust. Mus. 17: 407-416

Killingly, D. J. (1976). Biochemical population genetics of Cunjevoi. B.Sc. (Hons) thesis, Univ. of Sydney

Koehn, R. K., Milkman, R., Mitton, J. B. (1976). Population genetics of marine pelecypods. IV. Selection, migration and genetic differentiation in the blue mussel Mytilus edulis. Evolution 30: 2-32

Kwast, K. E., Foltz, D. W., Stickle, W. B. (1990). Population genetics and systematics of the Leptasterias hexactis (Echinodermata: Asteroidea) species complex. Mar Biol. 105: $477-489$

Lawson-Kerr, C., Anderson, D. T. (1978). Reproduction, spawning and development of the starfish Patiriella exigua (Lamarck) (Asteroidea: Asterinidae) and some comparisons with Patiriella calcar (Lamarck). Aust. J. mar. freshwat. Res. 29: 45-53

Levinton, J. S., Suchanek, T H. (1978). Geographic variation, niche, breadth and genetic differentiation at difterent geographic scales in the mussels Mytilus californianus and Mytilus edulis. Mar. Biol. 49: 363-375

McClary, D. J., Mladenov, P. V. (1989). Reproductive pattern in the brooding and broadcasting sea star Pteraster militaris. Mar. Biol. 103: 531-540

Nei, M. (1978). Estimation of average heterozygosity and genetic distance from a small number of individuals. Genetics 89: $583-590$

Paine, R. T (1966). Food web complexity and species diversity. Am. Nat. 100:65-75

Palumbi, S. R., Kessing, B. D. (1991). Population biology of the Trans-Artic exchange: MtDNA sequence similarity between Pacific and Atlantic sea urchins. Evolution 45 : $1790-1805$

Selander, R. K., Smith, M. H., Yang, S. Y., Johnson, W. E., Gentry, J. B. (1971). Biochemical polymorphism and systematics in the genus Peromyscus. I. Variation in the Oldfield Mouse (Peromyscus polionotus). Stud. Genet. 6: $49-90$

Siegismund, H. R., Müller, J. (1991). Genetic structure of Gammarus fossarum populations. Heredity 66 : 419-436

Slatkin, M. (1981). Estimating levels of gene flow in natural populations. Genetics 99: 323-335

Sokal, R. R., Sneath, P. H. A. (1963). Principles of numercial taxonomy. W. H. Freeman Co., San Francisco

Soulé, M. (1976). Allozyme variation: its determinants in space and time. In: Ayala, F. J. (ed.) Molecular evolution. Sinaur, Sunderland, MA, p. 60-77

Swofford, D. L., Selander, R. B. (1981). BIOSYS-1: a FORTRAN program for the comprehensive analysis of electrophoretic data in population genetics and systematics. J. Hered. 72: 281-283

Waller, D. M., Knight, S. E. (1989). Genetic consequences of outcrossing in the cleistogamous annual, Impatiens capensis. III. Interlocus associations. Heredity 63: 1-9 
Ward, R. D. (1990). Biochemical genetic variation in the genus Littorina (Prosobranchia: Mollusca). Hydrobiologia 193: $53-69$

Weir, B. S., Cockerham, C. C. (1984). Estimating F-statistics for the analysis of population structure. Evolution 38: $1358-1370$

Wright, S. (1968). Evolution and the genetics of populations.

This article was presented by J. M. Shick, Orono, Maine, USA
Vol 1 Genetic and biometric foundations. Univ. of Chicago Press, Chicago

Wright, S. (1978). Evolution and the genetics of populations. Vol. 4. Variability within and among natural populations. Univ. of Chicago Press, Chicago

Zar, J. H. (1984). Biostatistical analysis. 2nd edn. PrenticeHall, Englewood Cliffs

Manuscript first received: August 1, 1992

Revised version accepted: November 3, 1992 